\title{
Monitoring volcanoes in Mexico
}

\author{
Ramón Espinasa-Pereña ${ }^{\star \dagger \alpha}$, Raúl Arámbula ${ }^{\beta}$, Silvia $\operatorname{Ramos}^{\gamma}$, Katrin Sieron ${ }^{\delta}$, Lucia Capra ${ }^{\epsilon}$, \\ Ariadna Hernández-Oscoy ${ }^{\alpha}$, Miguel Alatorre $^{\gamma}$, Francisco Córdoba Montiel ${ }^{\delta}$ \\ ${ }^{\alpha}$ Centro Nacional de Prevención de Desastres, Mexico, Mexico. \\ $\beta$ Centro Universitario de Estudios en Vulcanología, Universidad de Colima, Colima, Mexico. \\ $\gamma$ Centro de Monitoreo Vulcanológico y Sismológico de Chiapas, Universidad de Ciencias y Artes de Chiapas, \\ Tuxtla Gutiérrez, Mexico.

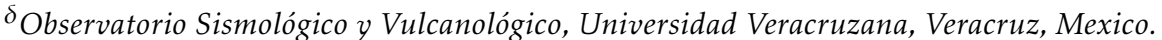 \\ ${ }^{\epsilon}$ Centro de Geociencias, campus Juriquilla, UNAM, Querétaro, Mexico.
}

\begin{abstract}
Mexico has at least 46 volcanic centers (including monogenetic volcanic fields) that are considered active or potentially active. Due to the federal governance of the country, the Centro Nacional de Prevención de Desastres (CENAPRED) is the entity responsible for monitoring natural hazards. Individual Mexican states also monitor active volcanoes within their territoryand through local universities. Specific observatories exist for Colima, Citlaltépetl (Pico de Orizaba), San Martín Tuxtla, El Chichón and Tacaná volcanoes, which are considered among the volcanoes with the highest hazard potential in the country. Details on instrumentation, data acquisition, hazard management, information dissemination and outreach are given for each volcano and observatory. The creation of a National Volcanological Service, based at CENAPRED and in full cooperation with local university-based observatories, would help consolidate all monitoring data and official information on active volcanoes at a single institution, procure and distribute resources, and allocate those resources according to the relative risk posed by the different volcanoes.
\end{abstract}

Este artículo está disponible en español: https://doi.org/10.30909/vol.04.S1.223246 [PDF ES].

\section{InTRODUCTION}

Mexico has a complex geology, comprising preCambrian metamorphic complexes, Mesozoic folded orogenic belts, and Tertiary and Quaternary continental and volcanic deposits [Morán 1985]. This complexity is a consequence of an intricate tectonic setting. Mexico is located at the southern end of the North America tectonic plate, where the Cocos and Rivera plates are subducting (Figure 1), creating the TransMexican Volcanic Belt (TMVB) stretching across the country from $\mathrm{W}$ to $\mathrm{E}$. The most active and hazardous volcanoes of the country are located along this mountain range [Espinasa-Pereña 2018]. At the NW coast of Mexico, the East Pacific Rise separates the Baja California peninsula from North America, and many volcanoes exist in this tectonic spreading environment. Also, along the eastern Sierra Madre, an alkaline volcanic province contains a few recent monogenetic fields and the San Martín Tuxtla volcano. At Mexico's southern end, the subduction of the Cocos Plate under the Caribbean Plate has created the Chiapanecan and Central American volcanic arcs, where El Chichón and Tacaná volcanoes are situated, respectively [Macías et al. 2008; 2015].

A recent study by Espinasa-Pereña [2018] concluded that 46 volcanic centers in Mexico could be considered

\footnotetext{
${ }^{*}$ Corresponding author: respinasa@yahoo.com.mx

$\dagger^{\dagger}$ Now at: Instituto de Geología, UNAM
}

as active, or potentially active. Among them, there are 26 Holocene stratovolcanoes and 15 monogenetic fields, which have produced at least one eruption in the last 10000 years. The list is completed by three calderas, which have erupted in the last 100000 years (one of them, Los Humeros, has been active in the Holocene), and two submarine volcanoes on the East Pacific Rise. Salton Buttes volcano (SA)in the United States of America, and Tajumulco, Santiaguito, Fuego, and Pacaya volcanoes Guatemala) also pose a risk to Mexico's population and territory, mainly due to the potential for ash fall.

At least half the population of Mexico lives within $100 \mathrm{~km}$ of an active volcano, mostly due to the mild climate and fertile soils of the TMVB, where the population is densest. With 60 million people at risk, Mexico is ranked fourth of countries with the highest number of people exposed to volcanic hazards, after Indonesia, the Philippines and Japan [Brown et al. 2015].

Due to the federal governance of the country, Centro Nacional de Prevención de Desastres (CENAPRED) is the legal entity responsible for the monitoring of natural hazards that could endanger the life and property of the population, including volcanic eruptions. Nevertheless, individual states with active volcanoes within their territory also conduct monitoring operations, usually through the efforts of a small community of geoscientists at local universities; local observatories exist for Colima volcano in the Colima-Jalisco state border, 


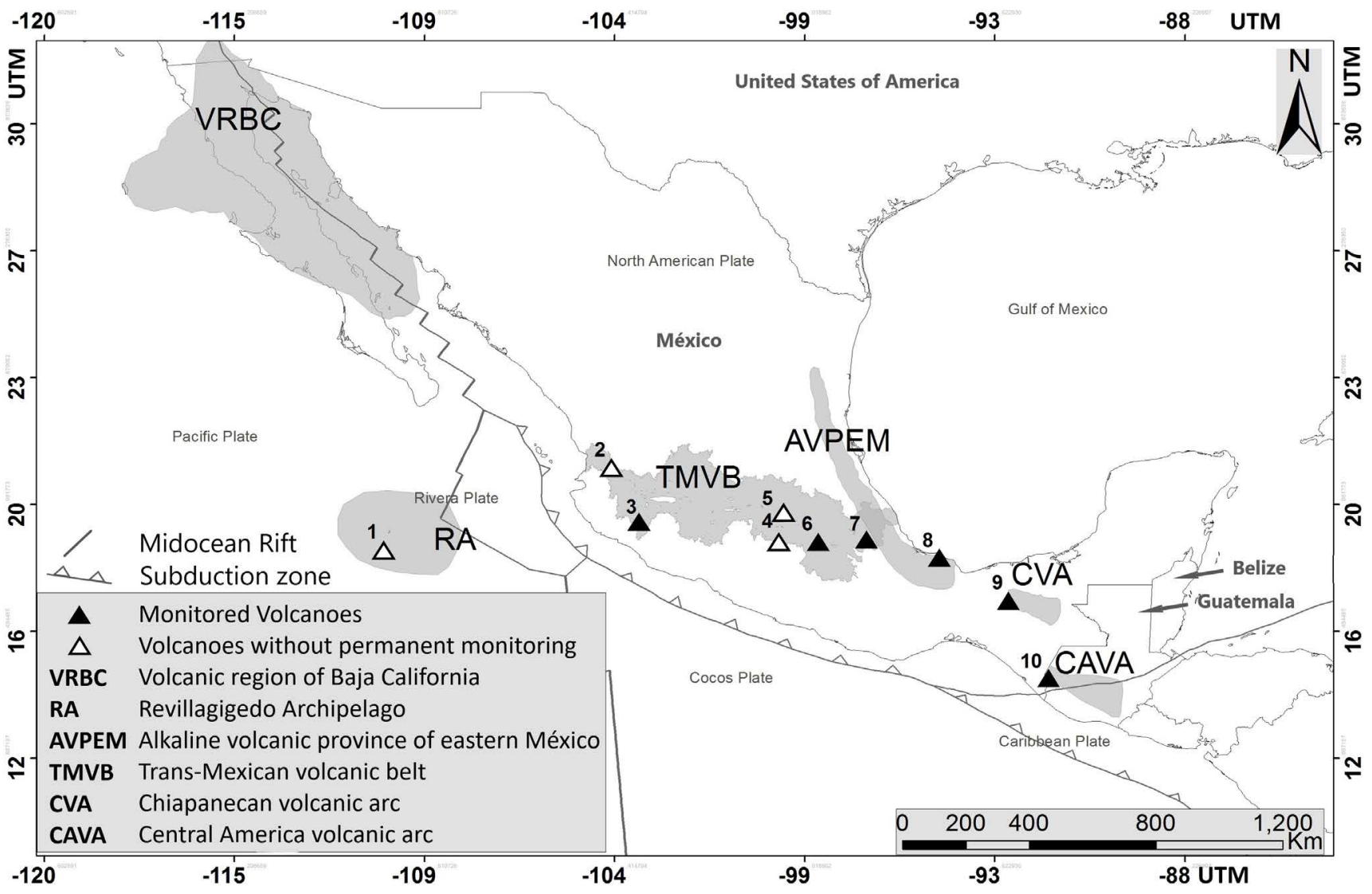

Figure 1: Tectonic setting of Mexico and the different volcanic provinces (grey regions). Main volcanoes mentioned in text: 1) Evermann, 2) Ceboruco, 3) Colima, 4) Nevado Toluca, 5) Jocotitlán, 6) Popocatépetl, 7) Citlaltépetl, 8) San Martín Tuxtla, 9) Chichón and 10) Tacaná.

Citlaltépetl and San Martín Tuxtla in Veracruz, and El Chichón and Tacaná, in Chiapas.

\subsection{Brief history of volcano monitoring in Mexico}

The first volcano observatories in Mexico were established in 1893 at Zapotlan, Jalisco, and in 1895 at Colima, Colima, by Fathers Arreola and Díaz, who made systematic observations of the activity at Colima volcano between 1893 and 1905 [Bretón-González et al. 2002]. Between 1943 and 1952, the Institute of Geology of the Universidad Nacional Autónoma de México (UNAM) established an observatory near Angáhuan, Michoacán, to study the activity of Paricutín volcano [Luhr et al. 1993].

In March-April 1982, and almost without warning, El Chichón (a.k.a. Chichonal) volcano, in Chiapas, produced a cataclysmic eruption that is recognised as the deadliest volcanic disaster in Mexico's history. The eruption killed an estimated 2,000 people, displaced several thousands, and caused strong social, economic and environmental impacts. Three years later, in September 1985, a large Mw 8.1 earthquake hit the country, causing the collapse of more than 300 buildings in Mexico City and an estimated
20,000 casualties. These disasters were the catalysts for the establishment of the Sistema Nacional de Proteccion Civil (SINAPROC) in 1988. Thanks to the support of the Japan International Cooperation Agency (JICA), the CENAPRED was created as the technical-scientific branch of SINAPROC, in charge of studying the phenomena that cause disasters and proposing public policies to prevent and mitigate their effects.

Colima volcano has been monitored by the University of Colima since 1989. The monitoring started with three short-period seismometers transmitting to the Central Campus in Colima City. Presently, the Centro Universitario de Estudios en Volcanología (CUEV) is responsible for the monitoring. The data acquired are shared with the Civil Protection agencies of Jalisco and Colima states and CENAPRED.

After nearly 70 years of inactivity, in 1994 Popocatépetl volcano, located $60 \mathrm{~km}$ from the outskirts of Mexico City, started showing signs of unrest. Back then, a single seismic station existed near the volcano, at Tlamacas (State of México), operated by the Servicio Sismológico Nacional (SSN). As soon as it was evident that the volcano was awakening, the first monitoring stations were installed, with telemetry to CENAPRED, thanks to aid and the donation of equipment by the United States Geological Survey (USGS) and their Vol- 
cano Disaster Assistance Program (VDAP). Therefore, CENAPRED assumed the responsibility of monitoring and alerting the population in case of an impending eruption.

Motivated by phreatic activity in 1986 , the SSN installed a seismic network at Tacaná in 1998. In 2003, with the creation of the Centro de Monitoreo Volcanológico y Sismológico (CMVS), hosted by the Universidad de Ciencias y Artes de Chiapas (UNICACH), volcano monitoring in Chiapas officially started.

The Observatorio Sismológico y Volcanológico (OSV) of the Centro de Ciencias de la Tierra at Universidad Veracruzana was created in 2014, when Veracruz State's seismic network was installed. This was as a response to a multitude of historical events, including the $17^{\text {th }}$ and $18^{\text {th }}$ century eruptions of Citlaltépetl (a.k.a. Pico de Orizaba) volcano, the 1793 eruptions of San Martín volcano, and the shallow 1920 earthquake (Mw 6.4), which triggered large-scale mass flow events in the mountain areas north of Citlaltépetl volcano and caused almost 700 deaths. The OSV was also established in response to recent disasters related to raintriggered lahars and other mass flow events in 2003 and 2012 at Citlaltépetl volcano [Rodríguez et al. 2006; Morales Martínez et al. 2016].

1.2 Which volcanoes are currently monitored in Mexico?

As of 2020, there are 6 volcanoes currently monitored in Mexico: Popocatépetl, Colima, Citlaltépetl (Pico de Orizaba), San Martín Tuxtla, Tacaná, and El Chichón.

Popocatépetl is considered the volcano that presents the highest risk potential, due to its location $60 \mathrm{~km}$ from the outskirts of Mexico City and the fact that over 25 million people live within a $100 \mathrm{~km}$ radius of its crater. Numerous historic eruptions are recorded, and the volcano has been continuously active for the last 25 years, with frequent effusive activity that creates lava domes within the crater (Figure 2), followed by Vulcanian explosions that cause subsequent dome destruction [Espinasa-Pereña 2012]. Popocatépetl is continuously monitored by CENAPRED.

Colima is the most active volcano in Mexico. In the last 430 years it has had about 50 significant eruptions, including sub-Plinian to Plinian eruptions (1818 and 1913, VEI 4) and frequent dome growth and subsequent collapse events, associated with Vulcanian explosions and pyroclastic density currents (PDC) [MedinaMartínez 1983; Bretón-González et al. 2002]. During the 1913 Plinian eruption, PDCs travelled up to 15 $\mathrm{km}$ from the crater [Capra et al. 2015, and references therein]. Today, similar flows would pose a high risk to communities near the volcano, where more than 10,000 people now live. In July 2015, two lava dome collapses associated with dome growth generated PDCs with an unexpected runout of $10.5 \mathrm{~km}$, making it the largest eruption since 1913 [Reyes-Dávila et al. 2016]. Usu- ally, an eruptive phase starts with lava dome growth, accompanied by the occurrence of pyroclastic and lava flows (Figure 2), and finally explosions that lead to the destruction of the lava dome [Arámbula-Mendoza et al. 2019]. Since 2011, lahar monitoring has been systematically implemented, in collaboration with the Geosciences Center at UNAM, Campus Querétaro.

Citlaltépetl, also named Pico de Orizaba, is the highest volcano in North America and the third most active volcano in Mexico, with numerous effusive and explosive eruptions during the $16^{\text {th }}, 17^{\text {th }}$ and $18^{\text {th }}$ centuries. Presently it has small active fumaroles near the summit crater. Nearly one million people, mostly in the cities of Orizaba, Nogales, and Ciudad Mendoza, to the south of the volcano, and Ciudad Serdán to the west, are vulnerable in case the volcano reactivates (Figure 2).

San Martín Tuxtla volcano, located to the southeast of Veracruz, is surrounded by a large and young monogenetic field and last erupted in 1793. It is $90 \mathrm{~km}$ from the city of Coatzacoalcos, and could affect 160000 people, mostly in the cities of San Andrés Tuxtla and Santiago Tuxtla. At present, Citlaltépetl and San Martín Tuxtla are both being continuously monitored by the OSV (Figure 2).

El Chichón, has a vigorous eruptive record in the Holocene, with at least 12 explosive eruptions in the past 8000 years [Scolamacchia and Capra 2015]. However, it was almost unknown until the March-April 1982 cataclysmic eruption (Figure 2). Currently, El Chichón volcano is monitored by the CMVS.

Tacaná, situated at the border with Guatemala, is the westernmost active volcano of the Central American Volcanic Arc. During the Holocene it produced at least four sub-Plinian to Plinian eruptions and nine additional explosive eruptions, the most recent of which occurred around 150 years ago [Macías et al. 2015]. It presented phreatic eruptions in 1949 and 1986, highlighting the threat it represents to more than 400000 people living in the vicinity of the volcano (the border city of Tapachula), which is the most densely populated region of Chiapas and is characterized by its important economic activity (Figure 2).

\section{HOW DO WE MONITOR THESE VOLCANOES?}

CENAPRED is in charge of the monitoring network at Popocatépetl volcano. Additionally, it performs annual spring and/or lake water sampling and analysis at Tacaná, El Chichón, San Martín, Citlaltépetl and Ceboruco volcanoes. Since 2015 it also receives the data of the monitoring network of Colima, by agreement with CUEV, and has cooperated with them in the acquisition and installation of monitoring equipment. Seismic data from the stations near Citlaltépetl and San Martín volcanoes are transmitted via internet (Earthworm software) to OSV and CENAPRED. The seismic stations at Tacaná belong to the SSN and their signals are received 

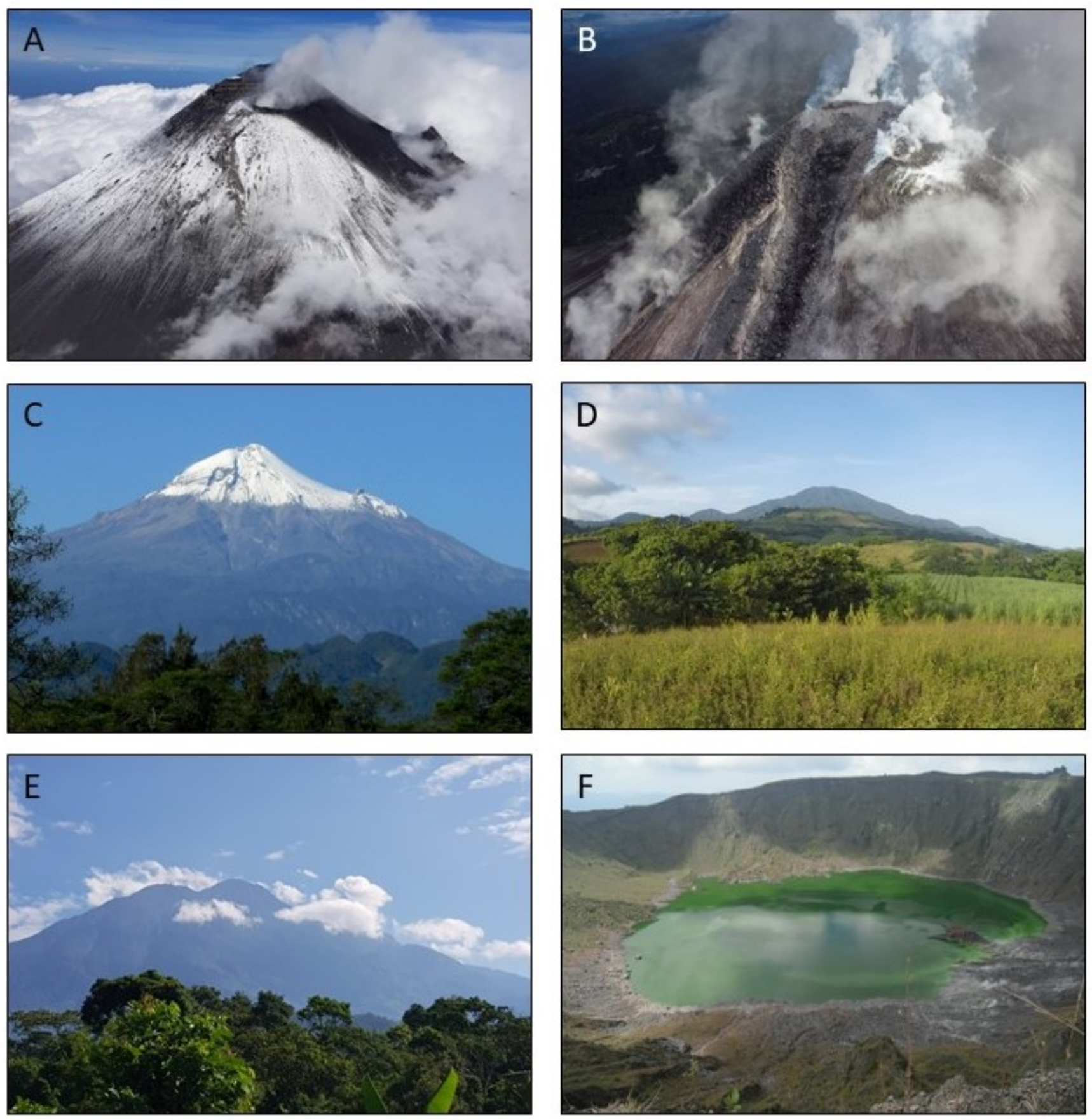

Figure 2: Main volcanoes monitored in México. [A] Popocatépetl viewed from the East, showing ashes and ballistic deposits over recent snow (photo credit: Ramón Espinasa-Pereña, July 2019). [B] Colima, showing one of the 2015 lava flows issuing from the crater (photo credit: Raúl Arámbula, July 2015). [C] Citlaltépetl (Pico de Orizaba) towering over the coastal plain (photo credit: Katrin Sieron, October 2018). [D] San Martin Tuxtla and several of the parasitic cones that form the Tuxtlas volcanic field (photo credit : Katrin Sieron, April 2010). [E] Tacaná volcano high above the Tapachula plains at the Guatemala border (photo credit: Ramón Espinasa-Pereña, August 2018). [F] Crater of El Chichón volcano left after the 1982 eruption, with a lake of sulfurous water (photo credit: Miguel Alatorre, October 2014). 
both at CMVS and CENAPRED.

In addition, other-less active-volcanic centers in Mexico are also monitored. In partnership with the Civil Protection agency of the State of México, seismometers were installed at Nevado de Toluca and Jocotitlán volcanoes by CENAPRED, but currently no signals are received due to communication problems. Evermann volcano, located at Socorro Island (State of Colima), has two seismic stations belonging to the SSN. Ceboruco volcano in Nayarit has a single SSN seismic station $9 \mathrm{~km}$ from the crater. SSN seismic stations are located within or near the Michoacán-Guanajuato, Chichinautzin and Xalapa-Naolinco volcanic fields. Although not for volcano monitoring, the calderas of La Primavera, Los Azufres (Michoacán) and Los Humeros (Puebla), as well as the geothermal fields of Cerro Prieto and Tres Vírgenes (Baja California) are instrumented by the Federal Electricity Commission (CFE), but their records are confidential.

2.1 Popocatépetl, States of Mexico, Puebla and Morelos

There are different types of real-time monitoring stations at Popocatépetl (Figure 3, Table 1), including seismometers, GPS, cameras, meteorological stations, a tiltmeter and an acoustic sensor. The monitoring staff of CENAPRED includes a total of 22 people (Table 2). All the data received and generated from the monitoring network at Popocatépetl volcano are stored in two ways:

1. Winston Database: A waveform server that uses MySQL to query data in conjunction with Earthworm software and, through Java, can be visualized with Swarm software (Winston, Earthworm and Swarm are programs developed by the USGS). The Winston base resides on a server that stores 60 days of data. A second Winston server, with data for the last 30 days, is used to generate different formats (heligrams, spectrograms, seisan, $\mathrm{dmx}$ and sac) through Earthworm software.

2. Historical database: Physical backup of 25 years of seismic data and images, on DVDs, hard drives and a recently integrated NAS of the native format of the seismic sensors (gcf, mssed). Camera images are saved as jpg. Deformation and gas data are backed up on the acquisition servers and a hard disk backup.

This information is publicly available through an official request letter to the General Director of CENAPRED, specifying type of data and time period required, and intended use. Data are delivered in native format, so the applicant can process the raw data for the purposes of their investigation. CENAPRED requests that when results are published, due credit is given.

\subsection{Colima volcano, States of Jalisco and Colima}

There are different types of real-time monitoring stations at Colima volcano (Figure 3, Table 1), including seismometers, cameras, acoustic sensors, meteorological stations, GPS, tiltmeter and EDM. The data are stored in DVDs and hard disks and can be made available upon request. The monitoring staff includes nine researchers and seven technicians (Table 2).

\subsection{Citlaltépetl and San Martín Tuxtla volcanoes,} State of Veracruz

Seismic data from the Veracruz Network, which includes eight broadband seismic stations located across the State plus the stations near Citlaltépetl and San Martín volcanoes (Figure 3), are transmitted and shared via internet (Earthworm software) with CENAPRED and the SSN. Small magnitude earthquakes are visualized on the Observatory's website (larger magnitude earthquakes are posted by the SSN). Data are stored continuously on OSV hard drives and can be requested through SSN. Two cameras are also installed on Citlaltepetl.

There are only two permanent members of the OSV, one seismologist and one volcanologist, complemented by students studying different disciplines (Table 2).

\subsection{El Chichón and Tacaná volcanoes, State of Chia- pas}

The monitoring equipment and techniques deployed at present at El Chichón and Tacaná volcanoes by the CMVS and SSN are presented in Table 1 and Figure 3, and include seismometers, GPS and EDM on El Chichón, seismometers and a camera on Tacaná. The permanent staff of the CMVS includes four persons ( $\mathrm{Ta}$ ble 2) and perform seismic, geochemistry, geodesy and visual monitoring. All the data are stored at the UNI$\mathrm{CACH}$; seismic data are shared with CENAPRED and with the SSN.

Unfortunately, for the monitoring of Tacaná volcano, although there are contacts between CENAPRED and Guatemalan institutes-the Instituto Nacional de Sismología, Volcanología, Meteorología e Hidrología (INSIVUMEH) and the Coordinadora Nacional para la Reducción de Desastres (CONRED)—no formal collaboration has been established yet. This is unfortunate because the edifice of Tacaná straddles the national border, and volcanoes in Guatemala also pose a risk to Mexico's population and territory due to ash fall.

\footnotetext{
*http://www .uv.mx/osv
} 

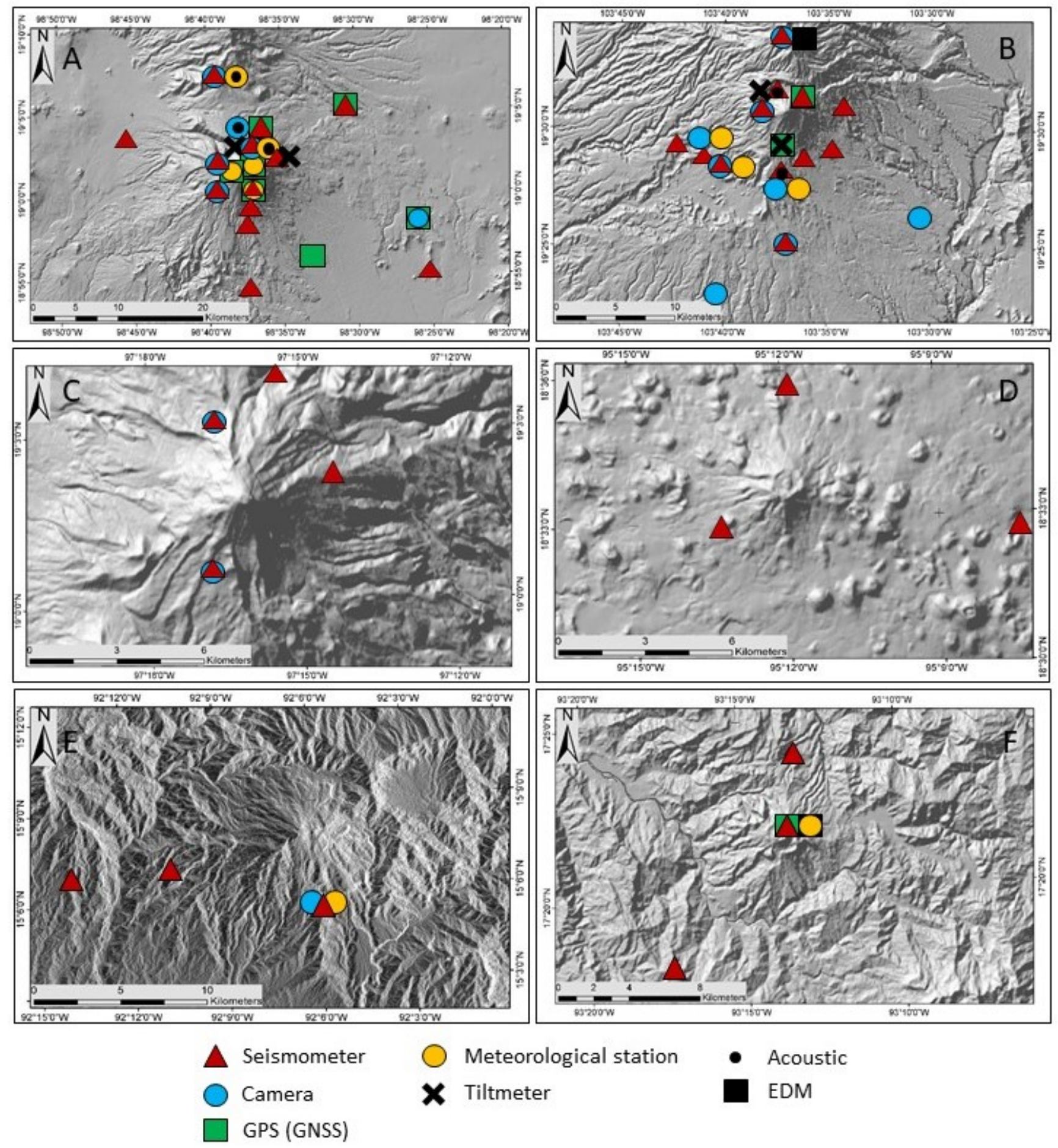

Figure 3: Monitoring stations at each of the main volcanoes monitored in México. [A] Popocatépetl; [B] Colima; [C] Citlaltépetl (Pico de Orizaba); [D] San Martin Tuxtla; [E] Tacaná, and [F] Chichón. Red triangles are seismic stations, while blue triangles are stations with seismic and other monitoring instruments (Acoustic sensor, GPS, tiltmeter, EDM, Camera and/or Meteorological station).

\section{Volcano Hazard Management}

\subsection{Hazard Maps}

Hazard maps of Mexican volcanoes have mostly been produced by individual researchers, without direct support from the institutions that monitor them. Nevertheless, the most recent version of Popocatépetl volcano's hazards maps [Martin-Del Pozzo et al. 2016] was financed by a special fund of the Interior Ministry for the prevention of natural disasters (Fondo para la Prevención de Desastres Naturales, FOPREDEN). 
Table 1: Monitoring equipment deployed at each volcano.

\begin{tabular}{rllcccccc}
\hline Institution & Volcano & \multicolumn{7}{c}{ Instruments } \\
\hline & Seismometers & $\begin{array}{c}\text { Acoustic } \\
\text { sensor }\end{array}$ & GPS & Tiltmeter & EDM & Camera $\begin{array}{c}\text { Meteo } \\
\text { station }\end{array}$ \\
\cline { 2 - 8 } CENAPRED & Popocatépetl & 16 & 1 & 7 & 2 & - & 9 & 5 \\
CUEV & Colima & 15 & 4 & 1 & 1 & 1 & 11 & 4 \\
OSV & San Martin-Tuxtla & 3 & - & - & - & - & - & - \\
& Pico de Orizaba & 3 & - & - & - & - & 2 & 3 \\
CMVS & El Chichón & 3 & - & 1 & - & 1 & - & 1 \\
& Tacaná & 4 & - & - & - & - & 1 & 1 \\
\hline
\end{tabular}

${ }^{*}$ Meteorological station

Table 2: Staff dedicated to volcano monitoring.

\begin{tabular}{rcccc}
\hline Institution & \multicolumn{4}{c}{ Staff } \\
\hline & Executives & Researchers & Technicians & Total \\
\cline { 2 - 5 } CENAPRED & 3 & 8 & 11 & 22 \\
CUEV & 2 & 7 & 7 & 16 \\
OSV & - & 2 & - & 2 \\
CMVS & 1 & 2 & 1 & 4
\end{tabular}

The official hazard map of Colima volcano was produced by researchers at CUEV in 2003 [Navarro-Ochoa et al. 2003], and is still used by Civil Protection. Nonetheless, based on the recent eruptive scenarios and new published data [i.e. Cortés et al. 2010; Capra et al. 2015; Macorps et al. 2018] a new version is in preparation, in cooperation with CENAPRED.

The hazard map for Citlaltépetl volcano was published by Sheridan et al. [2002] and eruptive scenario maps for San Martín volcano were published by Sieron et al. [2014].

The published hazard map for El Chichón volcano [Macías et al. 2008], which includes the differentiated hazards associated with PDCs, lahars and ash fall, has recently been complemented by a ballistic hazard map [Alatorre-Ibargüengoitia et al. 2016]. No comprehensive hazards map for Tacaná has been published yet, although efforts are being made to produce one [e.g. Vázquez et al. 2019a; b].

Table 3 includes the references to those maps that are available for download. Hazards maps for other volcanoes not currently monitored systematically, like Nevado de Toluca [Capra et al. 2008] and Ceboruco [Sieron et al. 2019], have also been published.

Additionally, the CENAPRED's web page provides access to the National Risk Atlas*. It includes layers with geological maps and hazard scenarios for Ceboruco, Citlaltépetl, El Chichón, Colima, Jocotitlán, Malinche, Nevado de Toluca, Popocatépetl, San Martín

*http://www.atlasnacionalderiesgos.gob.mx/archivo/visor-ca pas.html
Tuxtla, Tacaná, and Tres Vírgenes volcanoes, as well as a layer identifying all Pleistocene-Holocene monogenetic volcanic fields and another one which includes most of the Holocene stratovolcanoes in Mexico.

\subsection{Public alert systems}

For Popocatépetl, a volcanic traffic-light alert system is used, with three colors (green, yellow, and red) to identify the alert level for the population, and with different phases in each color to indicate actions that Civil Protection authorities and personnel should take [De la Cruz-Reyna and Tilling 2008]. This can be consulted online $e^{\dagger}$.

Recently, a volcanic traffic-light alert system of four colors (green, yellow, orange, and red) has been implemented at Colima volcano. This system can change in function of the volcanic activity and can be consulted at the Civil Protection website ${ }^{\ddagger}$.

There is an electronic volcanic traffic-light alert system (green-yellow-red, with increasing severity of hazard) in the town of Chapultenango (6000 inhabitants), located $10 \mathrm{~km}$ east from El Chichón volcano, that indicates the state of the volcano in real-time. At present, arrangements are being made to install further electronic Volcanic Traffic Lights in other localities around El Chichón and Tacaná volcanoes.

\footnotetext{
${ }^{\dagger}$ http://www . cenapred.gob.mx/es/Publicaciones/archivos/194CARTELSEMFORODEALERTAVOLCNICA.PDF

$\ddagger_{\text {http: //wWw.proteccioncivil.col.gob.mx/ }}$
} 
Table 3: Hazard maps of Mexican volcanoes. All online resources accessible as of January 2021.

\begin{tabular}{|c|c|}
\hline Volcano & Reference \\
\hline Popocatépetl & Martin-Del Pozzo et al. [2016] $]^{a}$ \\
\hline Popocatépetl ${ }^{\mathrm{b}}$ & Martin-Del Pozzo et al. $[2016]^{\mathrm{c}}$ \\
\hline Colima & Navarro-Ochoa et al. [2003] $]^{\mathrm{d}}$ \\
\hline Citlaltépetl & Sheridan et al. [2002] $]^{\mathrm{e}}$ \\
\hline San Martín Tuxtla ${ }^{f}$ & Sieron et al. $[2014]^{\mathrm{g}}$ \\
\hline Chichón & Macías et al. [2008] \\
\hline Chichón ${ }^{\mathrm{h}}$ & Alatorre-Ibargüengoitia et al. [2016] \\
\hline Nevado Toluca & Capra et al. [2008] \\
\hline Ceboruco & Sieron et al. [2019] \\
\hline \multicolumn{2}{|c|}{$\begin{array}{l}\text { a http://wWw. cenapred.gob.mx/es/Publicaciones/arc } \\
\text { hivos/357-CARTELMAPASDEPELIGROSDELVOLCNPOPOCATPE } \\
\text { TL.PDF } \\
\text { b nahuatl language }\end{array}$} \\
\hline \multicolumn{2}{|c|}{$\begin{array}{l}{ }^{c} \text { http://www. cenapred.gob.mx/es/Publicaciones/arc } \\
\text { hivos/357-CARTELMAPASDEPELIGROSDELVOLCNPOPOCATPE } \\
\text { TL(ENNHUALTLDEATLIXTAC).PDF }\end{array}$} \\
\hline \multicolumn{2}{|c|}{ d https://portal.ucol.mx/cueiv/mapapeligros.htm } \\
\hline \multicolumn{2}{|c|}{$\begin{array}{l}\text { e https://www.uv.mx/osv/vulcanologia/mapas-de-susc } \\
\text { eptibilidad-y-peligro-volcanico/ } \\
\text { f eruptive scenarios }\end{array}$} \\
\hline \multicolumn{2}{|c|}{$\begin{array}{l}\text { g https://www.uv.mx/osv/vulcanologia/mapas-de-susc } \\
\text { eptibilidad-y-peligro-volcanico/ }\end{array}$} \\
\hline
\end{tabular}

\subsection{Other systems}

The forecasts of volcanic ash dispersion [based on the FALL3D code, Folch et al. 2009] for both Popocatépetl and Colima volcanoes are published daily by the Centro de Ciencias Atmosféricas (Center of Atmospheric Sciences) and the Centro de Geociencias (Center of Geosciences) of UNAM, respectively, and are available through their web pages ${ }^{* \dagger}$.

A specially created app, which allows the identification of the evacuation routes and shelters at Popocatépetl, with the possibility of seeing them in Google Earth's Street View mode, is available online . $^{\ddagger}$ A similar app is presently being developed for Colima volcano.

\subsection{Scientific Advisory Committee}

Whenever the volcanic activity at Popocatépetl appears to be changing or increasing, CENAPRED convenes the Scientific Advisory Committee (CCA), a collegiate body which includes leading volcanologists from the Instituto de Geofísica (Geophysics Institute) of UNAM and other academic institutions, to analyze the available information and hazard assessments provided by

\footnotetext{
*http://grupo-ioa.atmosfera.unam.mx/pronosticos/index.php/ dispersion-de-cenizas

${ }^{\dagger}$ http://terra.geociencias. unam.mx/ceniza

$\ddagger_{\text {http : //www. atlasnacionalderiesgos.gob.mx/rutasvolcan/ }}$
}

CENAPRED, in order to make a diagnosis of the current processes and to issue recommendations about the Traffic-Light Alert System level. Civil Protection authorities then have the authority to act on this information to order evacuations, close or restrict access to certain areas or to take other measures.

A similar committee, integrated by leading researchers from Universidad de Colima and Civil Protection stakeholders, has been convened during crises at Colima volcano to discuss data acquired and, eventually, to change the alert level [Espinasa-Pereña et al. 2017]. CMVS also has the collaboration of a Scientific Advisory Committee, constituted by recognized national and international volcanologists.

\section{INFORMATION DISSEMINATION AND OUT- REACH}

\subsection{CENAPRED}

CENAPRED publishes, on a daily basis, a report on the activity of Popocatépetl volcano ${ }^{\S}$. Every time there is an ash emission CENAPRED informs the Centro Nacional de Comunicaciones (National Communications Center, CENACOM).

Many publications, including infographic posters, hazard maps, brochures and technical reports can be

\footnotetext{
$\S_{\text {https: }} / /$ wWw.gob.mx/cenapred
} 
downloaded from the CENAPRED web page*. As previously stated, CENAPRED interacts with all other volcano observatories in Mexico, and with the Civil Protection system, through the National Civil Protection Coordination, as recently during the Colima crisis in 2015 [Espinasa-Pereña et al. 2017]. In addition, strong collaboration is maintained with national and international institutions.

\subsection{CUEV, University of Colima}

Current volcanic activity is described in weekly reports published in the CUEV website ${ }^{\dagger}$. In case of major activity, special reports are published daily. In addition, the website includes information about Colima volcano and its monitoring system. Some data, such as seismograms, acoustigrams and webcams images are also accessible through the same web site; images from cameras dedicated to lahar monitoring are accessible online ${ }^{\ddagger}$. CUEV staff frequently visit the communities nearest to the volcano to inform about ongoing activity.

CUEV interacts with Civil Protection of Colima and Jalisco states through a direct channel of communication between the directors and the operational staff. Most of the information generated by CUEV is shared with CENAPRED. In addition, strong collaboration links are maintained with national and international institutions, such as the Centro de Geociencias and Instituto de Geofísica at UNAM, GFZ-Potsdam (Germany), USGS, University of Granada (Spain) and Université Savoie-Mont Blanc (France).

\subsection{OSV, Universidad Veracruzana}

Information and products derived from research projects are published in journals, books and other printed media, some of which can be found at the webpage ${ }^{\S}$. Any products deemed important for risk mitigation are handed to Civil Protection offices at state and municipal levels, as well as to CENAPRED.

\subsection{CMVS, UNICACH}

The UNICACH offers a bachelor program in Earth sciences, whose students participate in outreach activities regarding volcanic hazards in communities and schools around both volcanoes. Furthermore, staff of the CMVS actively and continuously participate in courses, press interviews (local TV, radio and newspapers), conferences and seminars related to volcanic hazards, risk assessment and the state of El Chichón and Tacaná volca-

\footnotetext{
${ }^{*}$ http://wWw. cenapred.gob.mx/PublicacionesWebGobMX/buscaind ex

† https://portal.ucol.mx/cueiv/

$\ddagger_{\text {http: }}$ //terra.geociencias. unam.mx/vulcano

$\S_{\text {http : //WWW .uv.mx/osv }}$
}

noes.

Information regarding El Chichón and Tacaná volcanoes, volcanic and seismic hazards and other themes related with Earth Sciences can be found online ${ }^{\mathbb{I I}}$.

CMVS collaborates with UNAM, CENAPRED, CUEV, Consejo Superior de Investigaciones Científicas de España, USGS, OVSICORI in Costa Rica, and INGEMMET in Peru.

\section{Needs, Challenges, AND future Perspec- TIVES}

Unfortunately, a lack of resources and personnel, together with cooperation and communication shortcomings between researchers at different institutions (and sometimes within one institution) severely handicap these monitoring efforts.

Public universities lack the resources to maintain the monitoring equipment installed on their volcanoes. Although equipment can be bought through the Consejo Nacional de Ciencia y Tecnología (CONACyT) grants and projects, there is usually little or no money for maintenance, so after a few years the equipment deteriorates or malfunctions.

The creation of a National Volcanological Service, working in a similar way to the existing Meteorological and Seismological Services, possibly based at CENAPRED and in full cooperation with local universitybased observatories, would help in concentrating all monitoring data and official information on active volcanoes at a single institution.

Espinasa-Pereña [2018] made a preliminary ranking of the 42 potentially active volcanoes in México, following the methodology of Ewert [2007]. Among the six most hazardous volcanoes (Popocatépetl, Colima, Ceboruco, Citlaltépetl, Tacaná, and El Chichón) only five are permanently monitored, and only Ceboruco lacks permanent sensors. Several other high-risk volcanoes lack monitoring systems, while most of the other volcanoes considered possibly active have no monitoring at all. A single institution in charge of volcano monitoring would aid in procuring and distributing resources and would also help in allocating those resources according to an analysis of the monitoring needs and the relative risk posed by the different volcanoes. It should ensure the availability of an annual stipend for equipment maintenance and general operations of the local observatories and allow for the hiring of researchers and technical staff at those observatories whose universities lack enough funds.

As the 2015 crisis at Colima volcano showed [Espinasa-Pereña et al. 2017], the Civil Protection authorities at the Federal level turn for advice to CENAPRED, also a Federal institution, rather than have to deal directly with the individual researchers or local

\footnotetext{
$\mathbb{I}_{\text {https: //monitoreo.unicach.mx/ }}$

$\|_{\text {https: //es-la.facebook.com/IIGERCC/ }}$
} 
scientific advisory committee. A National Volcanological Service would serve as a single source of information for decision makers, guaranteeing also that a single voice is used to address the concerns of all stakeholders (Federal and State authorities, Civil Protection and the media).

An additional advantage of a National Volcanological Service would be the homologation of the techniques and methodologies used for monitoring Mexico's volcanoes, and the standardization of the hazards maps and alert systems (Volcanic Traffic-Light Alert System), which currently is different at each observatory.

\section{AcKnOWledgements}

Paulino Alonso of CENAPRED provided some data on the location and instrumentation present at the monitoring stations on Popocatépetl. The comments of Yemerith Alpízar, Lizeth Caballero García, Pablo Forte, Matt Patrick, and three anonymous reviewers were instrumental in improving this article.

\section{Author CONTRIBUtions}

R. Espinasa-Pereña provided most of the text concerning CENAPRED, the eruptive activity and monitoring of Popocatépetl, and compiled the rest of the information. R. Arámbula and L. Capra provided the information on CUEV and the eruptive activity and monitoring of Colima volcano. S. Ramos and M. Alatorre provided the information on CMVS and the eruptive activity and monitoring of El Chichón and Tacaná volcanoes. K. Sieron and F. Córdoba provided the information on OVS and the eruptive activity and monitoring of Citlaltépetl and San Martín Tuxtla volcanoes. A. Hernández-Oscoy provided Figures 1, 2 and 3 and helped compile information on Popocatépetl and the other volcanoes.

\section{Data AVAILABILITy}

Data used for this article and/or further information can be found at the web page of CENAPRED (http $\mathrm{s}: / /$ ww. gob.mx/cenapred); specific information from the other observatories can be found on their respective webpages: CUEV (https://portal.ucol.mx/cueiv /), CMVS (https://monitoreo.unicach.mx/), OVS (ht tps://www.uv.mx/osv/).

\section{Copyright Notice}

(C) The Author(s) 2021. This article is distributed under the terms of the Creative Commons Attribution 4.0 International License, which permits unrestricted use, distribution, and reproduction in any medium, provided you give appropriate credit to the original author(s) and the source, provide a link to the Creative Commons license, and indicate if changes were made.

\section{REFERENCES}

Alatorre-Ibargüengoitia, M. A., H. Morales-Iglesias, S. G. Ramos-Hernández, J. Jon-Selvas, and J. M. Jiménez-Aguilar (2016). "Hazard zoning for volcanic ballistic impacts at El Chichón Volcano (Mexico)". Natural Hazards 81 (3), pp. 1733-1744. IssN: 15730840. DoI: $10.1007 / \mathrm{s} 11069-016-2152-0$.

Arámbula-Mendoza, R., G. Reyes-Dávila, T. Domínguez-Reyes, D. Vargas-Bracamontes, M. González-Amezcua, A. Martínez-Fierros, and A. Ramírez-Vázquez (2019). "Seismic Activity Associated with Volcán de Colima". Volcán de Colima. Springer Berlin Heidelberg, pp. 195-218. DoI: 10.1007/978-3-642-25911-1_1.

Bretón-González, M., J. J. Ramírez, and C. NavarroOchoa (2002). "Summary of the historical eruptive activity of Volcán De Colima, Mexico 1519-2000". Journal of Volcanology and Geothermal Research 117 (12), pp. 21-46. Dor: 10.1016/s0377-0273 (02) 00233- $\theta$.

Brown, S. K., M. Auker, and R. Sparks (2015). "Populations around Holocene volcanoes and development of a Population Exposure Index". Global Volcanic Hazards and Risk. Ed. by S. C. Loughlin, S. Sparks, S. K. Brown, S. F. Jenkins, and C. Vye-Brown, pp. 223-232. DoI: 10.1017/cbo9781316276273.006.

Capra, L., J. C. Gavilanes-Ruiz, R. Bonasia, R. SaucedoGiron, and R. Sulpizio (2015). "Re-assessing volcanic hazard zonation of Volcán de Colima, México". Natural Hazards 76 (1), pp. 41-61. DoI: 10.1007/s11069014-1480-1.

Capra, L., G. Norini, G. Groppelli, J. Macías, and J. Arce (2008). "Volcanic hazard zonation of the Nevado de Toluca volcano, México". Journal of Volcanology and Geothermal Research 176 (4), pp. 469-484. IssN: 03770273. DoI: 10.1016/j . jvolgeores. 2008.04.016.

Cortés, A., V. Garduño, J. Macías, C. Navarro-Ochoa, J. Komorowski, R. Saucedo, and J. Gavilanes (2010). "Geologic mapping of the Colima volcanic complex (Mexico) and implications for hazard assessment". Stratigraphy and Geology of Volcanic Areas. Geological Society of America. Dor: 10.1130/2010.2464(12).

De la Cruz-Reyna, S. and R. I. Tilling (2008). "Scientific and public responses to the ongoing volcanic crisis at Popocatépetl Volcano, Mexico: Importance of an effective hazards-warning system". Journal of Volcanology and Geothermal Research 170 (1-2), pp. 121-134. ISSN: 0377-0273. Dor: 10.1016/j . jvolgeores . 2007. 09.002.

Espinasa-Pereña, R. (2012). Historia de la actividad del Volcán Popocatépetl 17 años de erupciones. CENAPRED, Mexico.

- (2018). "Evaluación del riesgo relativo de los volcanes en México". VIII Foro Internacional: Los volcanes y su impacto, pp. 168-173.

Espinasa-Pereña, R., A. Nieto-Torres, and C. Gutiérrez (2017). "Manejo de las crisis volcánicas de 2012 y 2013 en el Popocatépetl y de 2015 en el volcán Fuego 
de Colima”. Revista de Administración Pública 52 (2), pp. 171-188.

Ewert, J. W. (2007). "System for Ranking Relative Threats of U.S. Volcanoes". Natural Hazards Review 8 (4), pp. 112-124. DoI: 10.1061 / (asce ) 1527 6988(2007) 8:4(112).

Folch, A., A. Costa, and G. Macedonio (2009). "FALL3D: A computational model for transport and deposition of volcanic ash". Computers E Geosciences 35 (6), pp. 1334-1342. DoI: $10.1016 /$ j . cageo. 2008. 08.008 .

Luhr, J. F., T. Simkin, and M. Cuasay (1993). Partcutin: the volcano born in a Mexican cornfield. US Geoscience Press.

Macías, J. L., J. L. Arce, P. W. Layer, R. Saucedo, and J. C. Mora (2015). "Eruptive History of the Tacaná Volcanic Complex". Active Volcanoes of the World. Springer Berlin Heidelberg, pp. 115-138. DoI: 10 . 1007/978-3-642-25890-9_6.

Macías, J. L., L. Capra, J. L. Arce, J. M. Espíndola, A. García-Palomo, and M. F. Sheridan (2008). "Hazard map of El Chichón volcano, Chiapas, México: Constraints posed by eruptive history and computer simulations". Journal of Volcanology and Geothermal Research 175 (4), pp. 444-458. Dor: $10.1016 / \mathrm{j}$. jvolgeores.2008.02.023.

Macorps, E., S. J. Charbonnier, N. R. Varley, L. Capra, Z. Atlas, and J. Cabré (2018). "Stratigraphy, sedimentology and inferred flow dynamics from the July 2015 block-and-ash flow deposits at Volcán de Colima, Mexico". Journal of Volcanology and Geothermal Research 349, pp. 99-116. Dor: $10.1016 / j$. jvolgeores.2017.09.025.

Martin-Del Pozzo, A., L. Arana, R. Bonasia, L. Capra, G. Cordoba, R. Cortés, H. Delgado, D. Ferrés, R. Fonseca, J. García, G. Gisbert, M. Jaimes, J. Macías, J. Portocarrero, S. Salinas, C. Siebe, and E. Tellez (2016). Mapas de peligros del volcán Popocatépetl. [English language] [Nahuatl language]. Secretaría de Gobernación. [Map scala 1: 100,000].

Medina-Martínez, F. (1983). "Analysis of the eruptive history of the Volcán Colima, Mexico,1560-1980". Geofísica Internacional 22 (2), pp. 157-178.

Morales Martínez, M. A., C. M. Welsh Rodríguez, L. C. Ruelas Monjardín, B. Weissling, K. Sieron, and C. A. Ochoa Martínez (2016). "Afectaciones por posible asociación de eventos hidrometeorológicos y geológicos en los municipios de Calcahualco y Coscomatepec, Veracruz". Teoría y Praxis 12 (Especial, Octubre 2016), pp. 31-49. ISSN: 1870-1582. DOI: 10.22403 / uqroomx/typne2016/02.

Morán, D. J. (1985). Geologıa de la República Mexicana: Instituto Nacional de Estadıstica. Geografia e Informática, México DF, México. IsBN: 68-881-060-6.

Navarro-Ochoa, C., A. Cortés, and A. Téllez (2003). Mapa de peligros del Volcán de Fuego de Colima. http:
/ / wWw - atlasnacionalderiesgos . gob . mx / archivo / peligros - colima . html. Universidad de Colima, México. [Map scala 1: 100,000].

Reyes-Dávila, G. A., R. Arámbula-Mendoza, R. Espinasa-Pereña, M. J. Pankhurst, C. Navarro-Ochoa, I. Savov, D. M. Vargas-Bracamontes, A. CortésCortés, C. Gutiérrez-Martínez, C. Valdés-González, T. Domínguez-Reyes, M. González-Amezcua, A. Martínez-Fierros, C. A. Ramírez-Vázquez, L. Cárdenas-González, E. Castañeda-Bastida, D. M. Vázquez Espinoza de los Monteros, A. Nieto-Torres, R. Campion, L. Courtois, and P. D. Lee (2016). "Volcán de Colima dome collapse of July, 2015 and associated pyroclastic density currents". Journal of Volcanology and Geothermal Research 320, pp. 100106. Dor: 10.1016/j . jvolgeores. 2016.04.015.

Rodríguez, S. R., I. Mora-González, and J. L. MurrietaHernández (2006). "Flujos de baja concentración asociados con lluvias de intensidad extraordinaria en el flanco sur del volcán Pico de Orizaba (Citlaltépetl), México". Boletín de la Sociedad Geológica Mexicana 58 (2), pp. 223-236.

Scolamacchia, T. and L. Capra (2015). "El Chichón Volcano: Eruptive History". Active Volcanoes of the World. Springer Berlin Heidelberg, pp. 45-76. DoI: 10.1007/ 978-3-642-25890-9_3.

Sheridan, M., G. Carrasco-Núñez, B. Hubbard, C. Siebe, and S. Rodríguez (2002). Mapa de Peligros del Volcán Citlaltépetl (Pico de Orizaba). Institutes of Geology, Geophysics and Geography of UNAM, and Governments of Veracruz and Puebla States.

Sieron, K., D. Ferrés, C. Siebe, R. Constantinescu, L. Capra, C. Connor, L. Connor, G. Groppelli, and K. González Zuccolotto (2019). "Ceboruco hazard map: part II-modeling volcanic phenomena and construction of the general hazard map". Natural Hazards 96 (2), pp. 893-933. IssN: 1573-0840. DOI: 10 . $1007 / \mathrm{s} 11069-019-03577-5$.

Sieron, K., L. Capra, and S. Rodríguez-Elizararrás (2014). "Hazard assessment at San Martín volcano based on geological record, numerical modeling, and spatial analysis". Natural Hazards 70 (1), pp. 275297. DoI: $10.1007 / \mathrm{s} 11069-013-0807-7$.

Vázquez, R., R. Bonasia, A. Folch, J. L. Arce, and J. L. Macías (2019a). "Tephra fallout hazard assessment at Tacaná volcano (Mexico)". Journal of South American Earth Sciences 91, pp. 253-259. DOI: $10.1016 / j$. jsames.2019.02.013.

Vázquez, R., J. L. Macías, J. L. Arce, G. Cisneros, and R. Saucedo (2019b). "Numerical simulation of blockand-ash flows for different eruptive scenarios of the Tacaná Volcanic Complex, México-Guatemala". Journal of Volcanology and Geothermal Research 373, pp. 36-50. Dor: 10.1016/j . jvolgeores. 2019.01.026. 